\title{
MODUL PEMBELAJARAN MEMBACA PEMAHAMAN TEKS CERITA PETUALANGAN UNTUK SISWA KELAS IV SEKOLAH DASAR
}

\author{
Innany Mukhlishina \\ Universitas Muhammadiyah Malang \\ Email:innasensei@yahoo.co.id
}

\begin{abstract}
This research and development aimed to produce reading comprehension learning module of adventure story text for grade IV elementary school. The step of research and development used in this study were: (preliminary study, (2) planning, (3) product development, (4) product validation, (5) revision 1, (6) product try out, (7) revision 2, and (8) final product. The result of expert validation of fiction prose learning $92 \%$ with very valid criteria and the result of expert validation of prose fiction appreciation $100 \%$ with very valid criteria. The module application data were obtained from teacher questionnaire responses $90 \%$ with very good criteriaand student questionnaire responses $92 \%$ with very good criteria. The effectiveness data were obtained of studet learning outcomeswere more than the minimum completeness criteria (KKM) and the average of students learning activities $90 \%$ with very active criteria. The attractiveness data wereobtained from students questionnaire responses $92 \%$ with interesting criteria. Based on the above results, the reading comprehension learning module of adventure story texts has very valid, very good, effective, and attractive criteria to use in learning at grade IV of elementary school.
\end{abstract}

Keyword: Module, Reading Comprehension, Adventure Story Text, Elementary School

\begin{abstract}
Abstrak:Penelitian ini bertujuan untuk menghasilkan modul pembelajaran membaca pemahaman teks cerita petualangan untuk siswa kelas IV Sekolah Dasar. Langkah-langkah penelitian dan pengembangan yang digunakan dalam penelitian ini yaitu: (1) studi pendahuluan, (2) perencanaan,(3) pengembangan produk, (4) validasi produk, (5) revisi 1, (6) uji coba produk, (7) revisi 2, dan (8) produk akhir. Hasil validasi ahli pembelajaran prosa fiksi sebesar $92 \%$ dengan kriteria sangat valid dan validasi ahli apresiasi prosa fiksi sebesar $100 \%$ dengan kriteria sangat valid. Data keterterapan modul diperoleh dari angket respon guru sebesar 90\% dengan kriteria sangat baik dan angket respon siswa sebesar 92\% dengan kriteria sangat baik. Data keefektifan diperoleh dari hasilbelajar siswa yang lebih dari KKM dan rata-rata aktivitas belajar siswa sebesar $90 \%$ dengan kriteria sangat aktif. Data kemenarikan diperoleh dari angket respon siswa sebesar $92 \%$ dengan kriteria menarik. Berdasarkan hasil tersebut, modulpembelajaran membaca pemahaman teks cerita petualangan sangat valid, sangat baik, efektif,dan menarik digunakan dalam pembelajaran di kelas IV Sekolah Dasar.
\end{abstract}

Kata kunci: Modul, Membaca Pemahaman, Teks Cerita Petualangan, Sekolah Dasar

\section{PENDAHULUAN}

Keterampilan membaca merupakan hal yang sangat penting dan berfungsi secara efektif dalam masyarakat terpelajar (Burns dkk, 1996:5). Setiap aspek kehidupan melibatkan kegiatan membaca. Keterampilan membaca merupakan salah satu keterampilan berbahasa yang harus dikuasai oleh siswa SD. Annisa (2013:3) juga mengatakan bahwa keterampilan membaca siswa di sekolah dasar masih rendah. Hal ini ditandai dengan sikap siswa yang enggan saat pelajaran membaca sehingga kurangnya pemahaman siswa untuk menyelesaikan materi yang disajikan dalam aspek membaca. Selain itu, siswakurang tertarik pada kegiatan membaca karena keterbatasan bahan bacaan. Terlebih membaca merupakan keterampilan yang harus dikuasai siswa SD terutama membaca karya sastra anak.Satra anak meliputi puisi, prosa, pantun, dan drama. Pembelajaran membaca pemahaman prosa anak berupa teks cerita petualangan merupakan materi yang harus diajarkan pada siswa kelas IV SD. Hal ini efektif dalam menanamkan nilai-nilai baik kepada anak karena anak akan mudah menyerap gambaran nilai-nilai baik tersebut dari isi sebuah teks petualangan yang telah dibaca.

Studi pendahuluan yang dilakukan di kelas IV SDN Klojen meliputi observasi, wawancara, dan kajian buu ajar. Hasil observasi menunjukkan bahwa pembelajaran membaca teks cerita 
petulalangan belum efektif. Sebagian besar siswa tidak bersemangat ketika membaca teks cerita petualangan pada buku, siswatidak memperhatikan teks cerita petualangan yang dibacakan oleh temannya, hasil rangkuman siswa tidak sesuai dengan teks cerita petualangan, dan hasil belajar siswa rendah.

Hasil wawancara guru mengatakan bahwa siswa kurang tertarik membaca, siswatidak meperhatikan ketika temannya membaca, kemampuan siswa menjawab pertanyaan berkaitan teks yang sudah dibaca masih rendah, dan siswakesulitan menceritakan kembali teks yang telah dibaca. Guru mengatakan bahwa waktu yang terbatas untuk melatih keterampilan membaca di kelas karena banyak materi lain yang harus diajarkan pada siswa. Guru membutuhkan bahan ajar berupamodul yang dapat digunakan siswa secara mandiri untuk mengatasi permasalahan tersebut. Buku ajar yang digunakan hanya LKS dan buku siswa.

Kajian buku yang digunakan guru dalam pembelajaran membaca teks cerita petualangan, ditemukan bahwa teks cerita petualangan yang disajikan dalam buku belum sesuai dengan karakteristik teks cerita petualangan. Buku belum menampilkan pertanyaan yang dapat mendorong siswamemahami unsur-unsur dalam cerita yang telah dibaca. Berdasarkan unsur penampilannya, terdapat sedikit ilustrasi gambar yang memperkuat susasana dalam teks cerita petualangan. Pada LKS yang digunakan lebih banyak berisi latihan soal terkait pembelajaran tematik sehingga porsi membaca teks cerita petualangan sangat minim (kajian buku siswa kelas IV).

Hasil membaca siswa meliputi menjawab pertanyaan berkaitan dengan teks dan menceritakan kembali teks yang telah dibaca. Berdasarkan hasil membaca siswa terdapat 23 siswa (72\%) dari 32 siswa yang mendapat nilai di bwah 70 . Hasil belajar yang rendah ini dikarenakan siswakurang memahami bacaan yang dibaca dan siswa kurang memahami setiap pertanyaan yang telah disediakan.

Oleh karena itu, dikembangkan bahan ajar berupamodul pembelajaran membaca pemahaman teks cerita petualangan. Keterbatasan waktu dan ruang dapat diatasi dengan penggunaan modul. Modul dapat digunakan siswa untuk belajar mandiri dan memahami setiap teks yang disajikan. Modul memberikan kesempatan kepada siswa untuk mempelajari materi pembelajaran secara tuntas karena materi dikemas dalam kesatuan yang utuh. Modul dapat membuat siswa termotivasi untuk belajar.

Modul yang akan dikembangakn dilengkapi lembar kerja dengan pola booktalk. Brown (1994:1) menyatakanbahwa booktalk merupakan lembar kerja yang digunakanguru dan siswa dalampembelajaran cerita yang berisi: (a) petunjuk pengisian, (b) lembar pertanyaan, (c) lembar tanggapan, (d) lembar perbandingan, dan (e) lembar perbedaan.

Penelitian tentang keterampilan membaca pernah dilakukan sebelumnya. Penelitian yang pernah dilakukan diantaranya oleh Denna Delawati Chrisyarani pada tahun 2014 yang berjudul "Pengembangan Modul Keterampilan Membaca dan Menulis Teks Percakapan Berbentuk Komik Siswa KelasV SDN Ngreco III Kabupaten Pacitan". Hasil penelitiantersebut menyebutkan bahwamodul keterampilan membaca dan menulis teks percakapan berbentuk komik yang dikembangkan memiliki kriteria sangat valid, sangat praktis, sangat menarik,dan sangat efektif.

Penelitian tentang keterampilan membaca lainnya yaitu oleh Dewi Pusposari pada tahun 2010 yang berjudul Peningkatan Kemampuan Membaca Cerita Fiksi Realistik Siswa Kelas 5SDN Arjowinangun Malang melalui Booktalk. Hasil penelitian tersebut menunjukkan bahwa pemanfaatan booktalk dapat meningkatkan pemahaman membaca cerita fiksi realistik kelas 5 SDN Arjowinangun Malang. Hal ini ditandai dengan adanya gradasi peningkatan kemampuan membaca siswa pada setiap siklusnya.

Tujuan penelitian dan pengembangan yang dilakukan untuk menghasilkan modul pembelajaran membaca pemahaman teks cerita petualangan untuk siswa kelas IV SDN Klojen Malang. Penelitian dan pengembangan modul pembelajaran membaca pemahaman teks cerita petualangan penting dilaksankan agar dapat bermanfaat antara lain: (1) Modul 
ini diharapkan dapat memudahkan siswa untuk belajar mandiri, menarik minat siswa untuk membaca, modul dengan lembar kerja pola booktalk dapat membantu siswa untuk memahami cerita yang dibaca, membantu siswa untuk memperoleh maknadan informasi yang terkandung dalamteks cerita yang dibaca, dan teks cerita petualangan pada modul ini sesuai dengan perkembangan siswa kelas IV sekolah dasar; (2) Modul ini menjadi salah satu alternatif bahan ajar yang dapat digunakan guru untuk menunjang pembelajaran membaca teks cerita petualangan, mengatasi keterbatasan dan kelemahan bahan ajar membaca teks cerita petualangan yang selama ini digunakan dalam pembelajaran, dan memudahkanguru untuk mengatasi keterbatasan waktu dalam pembelajaran karena siswa dapat belajar mandiri menggunakan modul ini; (3) Modul ini dapat dijadiaknsebagai bahan ajar pembelajaran membaca pemahaman teks cerita petualangan untuk kelas IV sekolah dasar. Modul ini dapat melengkapi bahan ajar lainnya yang terdapat di sekolah. Modul ini memudahkan sekolah dalammenyediakan bahan ajar pembelajaran membaca pemahaman.

\section{A. Modul Pembelajaran}

Setyosari dan Effendi (1990:9) menyatakan bahwa modul merupakan suatu program pembelajaran mengenai satu bahasan tertentuyang disusun secara sistematis, operasional, terarah, digunakan siswa, dan disertai pedoman penggunaannya bagi siswa maupun guru. Sejalan dengan itu, Direktorat Tenaga Kependidikan Direktorat Jenderal Peningkatan Mutu Pendidik dan Tenaga Kependidikan Departemen Pendidikan Nasional (2008:3) mengatakan bahwa modul merupakan bahan ajar cetak yang dirancang untuk dapat dipelajari secara mandiri oleh peserta didik. Berdasarkan pengertian modul di atas dapat disimpulkan bahwa modul adalah bahan ajar yang disusun secara sistematis,operasional, dan terarah untuk digunakan siswa secara mandiri dalammencapai tujuan pembelajaran pada modul.

Direktorat Tenaga Kependidikan Direktorat Jenderal Peningkatan Mutu
Pendidik dan Tenaga Kependidikan Departemen Pendidikan Nasional (2008:3-5) menyatakan bahwa sebuah modul dikatakan baik dan menarik apabila terdapat kriteria sebagai berikut: (1)SelfInstruction, yaitu modul memungkinkan siswabelajar mandiri dan tidak tergantung pada pihak lain; (2) Self Contained,yaitu seluruh materi pembelajaran yang dibutuhkan termuat dalam modul secara utuh; (3) Stand Alone (berdiri sendiri), yaitu modul bisa dikategorikan sebagai media yang berdiri sendiri; (4)Adaptif (memiliki daya adaptasi),yaitu modul hendaknya memiliki daya adaptasi yang tinggi terhadap perkembangan ilmu dan teknologi serta fleksibeldigunakan di berbagai perangkat keras; (5) User Friendly (bersahabat/akrab),yaitu modul hendaknya memenuhi kaidah bersahabat/akrab dengan pemakainya.

Kegiatan pembelajaran menggunakan modulmemilikikelebihan dan kelemhaan. Menurut Setyosari dan Effendi (1990:19) ada beberapa kelebihan yang diperoleh dengan belajar melalui penggunaan modul, yaitu: (1) motivasi siswa dapat ditingkatkan, (2) Hasilpekerjaansecepatnya dapat diketahui, (3) Hasilkerja yang dicapai sesuai dengan tingkat kemampuan siswa sendiri, (4) Bebanpelajaran terbagi secarameratapada setiapsemester, (5) Efisiensidanefektifitas tercapai. Penggunaan modul tidakterlepas dari kelemahannya, antara lain: (1) ikatan kelas menjadi renggang karena siswa lebihbanyak belajar mandiri, (2) perkembangan jiwa sosial kelas kurang mendapat perhatian karena adanya prinsip individualisasi belajar, (3) Aspek kemanusiaanseolah diabaikan karena manusiadianggap seperti mesin yang dapat berproduksi tinggi. Oleh karena itu dalammengembangkanmodul

memperhatikan kelebihandan kelemahan modulsehingga tujuanpembelajaran menggunakan modul dapat tercapaidengan baik.

\section{B. Booktalk}

Booktalk merupakan lembar kerja yang menarik untuk memahamkan siswa pada cerita. Di dalam booktalk terdapat ilustrasi gambar, daftar pertanyaan, dan petunjuk yang jelas sehingga dapat 
memberikan rangsangan dan membangkitkan imajinasi siswa untuk memahami teks cerita sekaligus menanggapi cerita yang telah dibaca. Brown (1994:1) menyatakan bahwa lembar kerja booktalk adalah lembar kerja yang digunakan guru dan siswa dalam pembelajaran cerita yang berisi: (a) petunjuk pengisian, (b) lembar pertanyaan, (c) lembar tanggapan, (d) lembar perbandingan, dan (e) lembar perbedaan. Manfaat booktalk yaitu memudahkan siswa dalam pembelajaran membaca pemahaman teks cerita petualangan meliputi pemahaman terhadap pelaku, latar, tema, dan rangkaian hal-hal lain yang ada dalam cerita. Booktalk juga memudahkan siswa untuk dapat menyimpulkan isi cerita petualangan yang telah dibaca.

\section{Hakikat Membaca}

Proses belajar yang efektifantara lain dilakukan melalui membaca. Menurut Nurhadi (2009:2) membaca adalahkegiatan memahami makna yang terdapat dalamtulisan. Tiga istilah yang sering digunakanuntuk memberikankomponen dasar dariproses membaca, yaitu recording, decoding, dan meaning. Proses recording dan decoding biasanya berlangsung pada kelas-kelas awal, yaitu SD kelas I, II,III yang dikenaldengan istilah membaca permulaan. Sementara itu proses memahami makna(meaning)lebih ditekankandikelas-kelas tinggi SD (Syafi'ie, 1999

Tarigan (2008:58)menyatakan bahwa membaca pemahaman adalah sejenis membaca yang bertujuan untukmemahami standar-standar atau norma-norma kesastraan,resensi kritis, drama tulis, dan pola-pola fiksi. Seseorang memerlukan kemampuan membaca yang memadai untukmemperoleh pemahaman ketikamembaca. Seseorang dikatakan memahami bacaan secara baik apabila mampu mengerti isi bacaan secaramenyeluruh.

\section{Hakikat Cerita Anak}

Cerita anakadalah ceritayang diperuntukkanbagianak-anak.Isinya tentang kehidupananak-anak, yaitu yang berkaitan dengan permainan, kesukaan, sifat-sifatnya,danperkembangannya.

Badriah (dalam Tarigan, Djago 1997: 11.38) mengemukakan bahwa cerita anak memiliki karkateristik sebagai berikut: (1) bahan dari kehidupan anak (2) dibuat untuk dinikmatioleh anakanak,(3)temanya sesuai dengan kehidupananak-anak,(4) bahasa sederhanadanmudahdipahami anak-anak, (5)konflik dapatmenuntunanakanakmenemukanjalankeluarbagikehidupa nnya,dan(6)mengandung nilai-nilai pendidikan.

Nurgiyantoro

(2013:221) menyatakan bahwa unsur intrinsik adalahunsur-unsur cerita fiksi yang secara langsung membentuk eksistensicerita yang bersangkutan. Sedangkan unsur ekstrinsik merupakan unsur yang berada di luar teks fiksi yang bersangkutan, tetapi mempunyai pengaruh terhadap cerita yang dikisahkan, baik langsung maupun tidak langsung.Unsur-unsur ceritaanak antaralain: alur, tokoh, tema, latar, amanat.

Jenis cerita anak terdiri atas: (a) novel, (b) cerpen, (c) fiksi formula, (d) fiksi sejarah, (e) fiksi fantasi, (f) fiksi formula, dan (g) fiksi biografis (Rumidjan, 2013:69). Cerita petualangan merupakan tema yang termasuk dalam dua jenis cerita anak, yaitu fiksi realistik dan fiksi fantasi.Nurgiyantoro (2013:15) menyebutkan karakteristik umum fiksi realistik adalah narasi fiksional yang menampilkan tokoh dengan karakter menarik yang dikemas dalam latar tempat dan waktu yang dimungkinkan.

\section{METODE PENELITIAN}

Penelitian ini merupakan penelitian pengembangan. Penelitian ini mengacu padamodelpengembangan Research and Development (R\&D) dari Borg \&Gall (1983) yang sudah dimodifikasi sehingga ada beberapa perubahan yang disesuaikandengan kebutuhan penelitian. Menurut Gall, Gall\& Borg (2003:573),peneliti dapat menyederhanakan tahapan penelitian menjadi enam langkah,seperti yang pernah dilakukan oleh Cunningham (1987) yakni menjadi 6 tahapan penelitian yaitu, (1) studi pendahuluan, 
(2) perencanaan, (3) pengembangan produk, (4) validasi produk, (5) uji coba produk skala terbatas, dan (6) produk akhir.

Langkah-langkah penelitian dan pengembangan yang digunakandalam penelitian ini yaitu: (1) studi pendahuluan, (2) perencanaan,(3) pengembangan produk, (4) validasiproduk, (5)revisi 1, (6) uji coba produk, (7) revisi 2,dan (8) produk akhir.

Tahap studi pendahuluan terdiri dari studi pustaka, survei lapangan, dan identifikasi masalah. Studi pustaka meliputi kajian pustaka tentang konsep pengembangan bahan ajarberupamodul,konsep lembar kerja booktalk,pembelajaran

membacapemahamandi sekolah dasar, konsep cerita petualanganuntuk anak sekolah dasar,dan hasil-hasil penelitian terdahulu yangrelevan dengan penelitian ini. Survei lapangan terdiri dari observasi dan wawancara. Observasi dilakukan pada saat pembelajaran membaca dikelas IVSDNKlojen Malang. Berdasarkan observasi diperoleh hasilbahwaminat baca siswa rendah dan rendahnya kemampuan siswa dalammemahami bacaan. Selain itu, berdasarkan hasil wawancara dengan guru kelas IV B diperoleh informasi bahwa bahan ajar yang digunakan dalam pembelajaran membaca pemahaman teks cerita petualangan hanya buku siswa dan LKS yang belum sesuai dengan karakteristik cerita petualangan.

Perencanaan meliputi kegiatan menganalisis $\mathrm{KI}, \mathrm{KD}$, dan materi, merumuskan tujuan pembelajaran, mengembangkan instrumen uji validasi produk.Pengembangan produk dilakukan dengan cara menyusun modul berdasarkan landasan teori tentang bahan ajar dan dilengkapi dengan pola lembar kerja booktalk. Modul yang dikembangkan terdiri dari pendahuluan, isi, dan penutup. Pendahuluan berisi kata pengantar, petunjuk penggunaan modul, bagian-bagian modul, kabar modul, dan daftar isi. Isi terdiri dari 2 penggalan. Setiap penggalan terdiri dari 2 pembelajaran. Setiap pembelajaran menampilkan 8 kegiatan yaitu tahukah kamu, ayo belajar, uraian materi, ayo membaca,ayo berlatih, ayo renungkan, dan kerjasama dengan orangtua. Pada akhir penggalan terdapat tes mandiri dan permainan. Teks cerita petualangan terdapat dalam kegiatan ayo membaca. Penutup beisi tes akhir modul untuk menguji kompetensi siswa, kamus katakata sulit, dan daftar pustaka. Pada kegiatan ayo berlatih, tugas, tes mandiri, dan tes akhir modul menggunakan lembar kerja dengan pola booktalk.

Validasi produk dilakukan oleh ahli pembelajaran prosa fiksi dan ahli apresiasi prosa fiksi. Data yang telah divalidasi dan masukan dari para ahli menjadi pertimbangan melakukan revisi 1 pada produk yang dihasilkan.

Revisi 1 dilakukan berdasarkan saran dan perbaikan dari hasil validasi ahli pembelajaran prosa fiksi dan ahli apresiasi prosa fiksi.Uji coba produk dilakukan kepada guru dan siswa untuk mengetahui

tingkat

\section{keterterapan,keefektifan,dan}

kemenarikan modul pembelajaran membaca pemahaman teks cerita petualangan. Setelah dilakukan uji coba lapangan skala terbatas,maka dilakukan revisi 2 untuk perbaikan.

Revisi 2 dilakukan berdasarkan saran dan perbaikan dari hasil uji coba lapangan skala terbatas. Produk akhir diperoleh setelah dilakukan revisi II dari hasil uji coba skala terbatas. Produk akhir berupa modul pembelajaran membaca pemahaman teks cerita petualangan untuk siswa kelas IV SDN Klojen Malang.

Subyek uji coba dalam penelitian ini meliputi ahli pembelajaran prosa fiksi, ahli apresiasi prosa fiksi, guru, dan siswa kelas IV SDN Klojen Malang.Jenis data yang diperoleh dari uji coba produk penelitian dan pengembangan ini berupa data kualitatif dan data kuantitatif. Data kualitatif diperoleh dari komentar dan saran perbaikan dari validator guru, dan siswa. Data kuantitatif berupaskorpenilaian yang diperoleh dari angket validasi ahli pembelajaran prosa fiksi, ahli apresiasi prosa fiksi, angket respon guru, angket respon siswa, hasil belajar siswa, dan aktivitas belajar siswa.

Instrumen pengumpulan data berupa angket validasi modul, angket respon guru, angket respon siswa, lembar penilaian, dan lembar observasi. Teknik analisis data yang digunakan dalam penelitian ini menggunakan teknik 
analisis deskriptif kualitatif dan deskriptif kuantitatif. Analisis data deskriptif kualitatif digunakan untuk mengolah data berupa komentar dan saran perbaikan berdasarkan hasil penilaian pada angket hasil validasi dan angket respon guru. Analisis deskriptif kualitatif digunakan untuk menganalisis kevalidan modul pembelajaran, keterterapan modul pembelajaran, analisis keefektifan modul pembelajaran, dan menganalisis kemenarikan modul pembelajaran.

\section{HASIL DAN PEMBAHASAN}

A. Proses Pengembangan Pengembangan modul pembelajaran membacapemahaman teks cerita petualangan ini disusun menggunakan model pengembangan Research and Development (R \& D) dari Borg \&Gall dengan langkah-langkah penelitian dan pengembangan yang digunakan dalam penelitian ini yaitu: (1) studi pendahuluan, (2) perencanaan, (3) pengembangan produk, (4) validasi produk, (5) revisi 1, (6) uji coba produk, (7) revisi 2, dan (8) produk akhir.

Studi pendahuluan meliputi survei lapangan, identifikasi masalah, dan studi lapangan. Berdasarkan studi pendahuluan diketahui bahwa penyelesaian permasalahan membaca pemahaman teks cerita petualangan tersebut dengan mengembangkan bahan ajar berupa modul sebagai pendamping bahan ajar berupa buku siswa dan LKS yang selama ini digunakan oleh guru. Modul pembelajaran membaca pemahaman teks cerita petualangan ini dilengkapi lembar kerja dengan pola booktalk yang memudahkan siswa memahami cerita yang dibaca. Pengembangan modul pembelajaran ini dapat menjadi solusi untuk mengatasi kebutuhan siswa.

Perencanaan yang dilakukan yaitu analisis Kompetensi Inti, Kompetensi Dasar,dan materi. Analisis KI,KD, dan materi dilakukan untuk menghasilkan indikator dan tujuan pembelajaran yang sesuai. Berdasaran indikator dan tujuan pembelajaran maka disusun rencana pelaksanaan pembelajaran beserta alat evaluasinya. Perencanaan selanjutnya yaitu mengembangkan instrumen uji validasi produk meliputi instrumen yang akan diberikan kepada ahli pembelajaran prosa fiksi,ahli apresiasi prosa fiksi, guru,dan siswa sebagai subyekcoba. Selain itu,instrumen yang dikembangkan adalah angket respon guru, angket respon siswa, dan lembar observasi aktivitas siswa. Selanjutnya,disusun modulpembelajaran membaca pemahaman teks cerita petualangan.

Tahap selanjutnya merupakan tahap pengembangan produk. Tahap ini dilaksanakan dengan membuat produk yang dikembangkan yaitu modul pembelajaran. Modul yang dikembangkan dilengkapi dengan pola lembar kerja booktalk. Validasi dilakukanoleh ahli pembelajaran prosa fiksi dan ahli apresiasi prosa fiksi.Validator ditentukan melalui penetapan kriteria. Data yang telah divalidasi dan masukan dari para ahli menjadi pertimbangan melakukan revisi 1 pada produk yang dihasilkan.Revisi 1 dilakukan berdasarkan saran dan perbaikan dari hasilvalidasi ahli pembelajaran prosa fiksi dan ahli apresiasi prosa fiksi.

Produk berupa modul pembelajaran yang telah direvisi berdasarkan penilaian danmasukan dari validasi ahli diujicobakan skala terbatas. Subyek uji coba yaitu guru dan siswa kelas IV SDN Klojen Malang yang berjumlah 32 siswa. Uji coba dilakukan dalam lima kali pertemuan. Kegiatan pembelajaran dilakukan langsung di dalam kelas dengan meggunakan modul yang telah dikembangkan. Selama proses uji cobadilakukan pengambilan data keterterapan, keefektifan, dan kemenarikan modul yang telah dikembangkan. Data keterterapan diambil dari instrumen pengumpulan data berupa angket respon guru dan angket respon siswa. Data keefektifan diperoleh dari hasil belajar siswa dan aktivitas hasil belajar siswa yang dikumpulkan melalui lembar penilaian dan lembar observasi. Data kemenarikan diperoleh melalui angket respon siswa. Hasil uji coba produk digunakan sebagai pedoman revisi 2 untuk perbaikan produk. Revisi 2 dilakukan berdasarkan saran dan perbaikan dari hasil uji coba lapangan skala terbatas.

Produk akhir diperoleh setelah dilakukan revisi 2 dari hasil uji coba skala terbatas. Produk akhirberupa modul pembelajaran membaca pemahaman teks 
cerita petualangan untuk siswa kelas IV SDN Klojen Malang siap digunakan. Produk akhir telah ditetapkan valid secara teoritik, memiliki keterterapan yang tinggi, efektif mencapai tujuan pembelajaran, dan menarik digunakan dalam pembelajaran membaca pemahaman teks cerita petualangan pada siswa kelas IV SD.

B. Analisis Data

Analisis data meliputi analisis data validasi ahli, analisis data keterterapan, analisis data keefektifan,dan analisisdata kemenarikan. Hasil validasi ahli pembelajaran prosa fiksi diperoleh persentase sebesar $92 \%$ dengan kriteria sangat valid. Sedangkan hasil validasi ahli apresiasi prosa fiksi diperoleh persentasesebesar $100 \%$ dengan kriteria sangat valid. Berdasarkan datakevalidan modul didapatkan rekapitulasi kevalidan sebesar $96 \%$ dengan kriteria sangat valid.

Tabel 1 Rekapitulasi Data Validasi Total Modul Pembelajaran Membaca Pemahaman Teks Cerita Petualangan

\begin{tabular}{lc}
\hline \multicolumn{1}{c}{ Aspek } & Validator (\%) \\
\hline $\begin{array}{l}\text { Pembelajaran Prosa } \\
\text { Fiksi }\end{array}$ & 92 \\
\hline Apresiasi Prosa Fiksi & 100 \\
\hline Jumlah & 192 \\
\hline Rata-rata & 96 \\
\hline
\end{tabular}

Data keterterapan modul diperoleh dari angket respon guru dan angket respon siswa. Berdasarkan perhitungan data angket respon guru diperoleh persentase sebesar 90\% dengan kriteria sangat baik. Berdasarkan perhitungan data angket respon siswa diperoleh persentase sebesar $92 \%$ dengan kriteria sangat baik. Berdasarkan data keterterapan modul didapatkan rekapitulasi sebesar $91 \%$ dengan kriteria sangat baik.

Tabel 2 Rekapitulasi Data Keterterapan Modul Pembelajaran Membaca Pemahaman Teks Cerita Petualangan

\begin{tabular}{lc}
\multicolumn{1}{c}{ Aspek } & Hasil (\%) \\
\hline Respon Guru & 90 \\
\hline Respon Siswa & 92 \\
\hline Jumlah & 182 \\
\hline Rata-rata & 91 \\
\hline \multicolumn{1}{c}{ Data } & keefektifan \\
\hline
\end{tabular}

Data keefektifan diperoleh dari hasil belajar dan aktivitas belajar. Hasil belajar siswa lebih dari KKM yang ditetapkan yaitu 70 sehingga modul dikatakan efektif. Berdasarkan perhitungan rata-rata aktivitas belajar siswa diperoleh persentase sebesar $90 \%$ dengan kriteria siswa sangat aktif.

Data kemenarikan diperoleh dari angket respon siswa. Berdasarkan angket respon siswa diperoleh persentase 92\% dengan kriteria sangat menarik. Secara keseluruhan siswa lebih bersemangat dalam belajar membaca pemahaman teks cerita petualangan dengan menggunakan modul pembelajaran ini. Berdasarkan data uji cobalapangan pada guru dan siswa kelas IV SDN Klojen Malang menunjukkan bahwa penggunaan modul pembelajaran membaca pemahaman teks cerita petualangan sangat baik, efektif, dan menarik untuk digunakan dalam pembelajaran.

Berdasarkan data yang dikumpulkan dan dianalisis, dilakukan revisi produk, yaitu revisi tahap 1 dan revisi tahap 2. Revisi tahap 1 dilakukan berdasarkan masukan dan saran dari ahli pembelajaran prosa fiksi dan ahli apresiasi prosa fiksi. Bagian-bagian yang direvisi antara lain: kata pengantar bisa dilengkapi dengan informasi bagianbagian isi modul (10 aktivitas yang konsisten), memperbaiki penggunaan kata seperti kata membaca diganti menjadi kata membacakan dan kata menceritakan kembali teks cerita petualangan dilengkapi dengan kalimat secara tertulis, sedikit revisi pada teknislatihan dan tayangan gambar yang digunakan, dan warna kurang tajam atau sedikit kabur.Revisi tahap 2 dilakukan berdasarkan masukan dan saran yang diperoleh saat uji coba lapangan. Bagian yang direvisi yaitu daftar kata pada tekateki silang.

\section{SIMPULAN}

Modul pembelajaran membaca pemahaman teks cerita petualangan terdiri dari pendahuluan,isi, dan penutup. Pendahuluan berisi kata pengantar, petunjuk penggunaanmodul, bagianbagian modul, kabar modul, dan daftar isi. Isi modul terdiri dari 2 penggalan. Setiap penggalan terdiri dari 2 pembelajaran. Setiap pembelajaran menampilkan 8 kegiatan yaitu tahukah kamu, ayo belajar, uraian materi, ayo membaca, ayo berlatih, tugas, ayo renungkan, dan kerjasama dengan orangtua. Pada akhir penggalan terdapat tes mandiri dan permainan. Teks cerita 
petualangan terdapat dalam kegiatan ayo membaca. Teks cerita petualangan diambil dari cerita petualangan berjudul "Nino Si Petualang Cilik" karya Agnes Bemoe. Teks cerita petualangan yang digunakan pada modul ini merupakan teks cerita petualangan bertema lingkungan dan sumber daya alam sesuai dengan kompetensi dasar. Pada teks cerita petualangan juga terdapat muatan budaya daerah-daerah yang terdapat di Indonesia. Penutup berisi tes akhir modul untuk menguji kompetensi siswa, kamus kata-kata sulit, dan daftar pustaka. Tes akhir modul menggunakan lembar kerja dengan pola booktalk. Berdasarkan hasil penelitian dan pengembangan yang telah dilakukan dapat disimpulkan bahwa modul pembelajaran membaca pemahaman teks cerita petualangan sangat valid, sangat baik diterapkan, efektif, dan menarik digunakan dalampembelajaran membaca pemahaman teks cerita petualangan di sekolah dasar.

\section{DAFTAR PUSTAKA}

Annisa,I.Z. 2013. Peningkatan Aktivitas dan Keterampilan Membaca Cerita Melalui Penerapan Metode Pembelajaran SQ3R. Jurnal Volume 01 Nomor 01 Tahun 2013. Hal 1-14

Borg, W.R. \& Gall, M.D. 1979. Educational Research anIntroduction, Third Edition. New York: Longman Inc.

Brown \& Teasdale. 1994. Booktalk.Melbourne: Longman Chesire Pty Limited.

Burns, R. \& Ross. 1996. Teaching Reading in Today's Elementary Schools. $6^{\text {th }}$ Edition. USA. Houghton Mifflin Company

Chrisyarani, D.D.2014. Pengembangan Modul Keterapilan Membaca dan Menulis Teks Percakapan Berbentuk Komik Siswa Kelas V SDN Ngreco III Kabupaten Pacitan. Tesis tidak diterbitkan. Malang: Universitas Negeri Malang
Direktorat Tenaga Kependidikan Direktorat Jenderal Peningkatan Mutu Pendidik dan Tenaga Kependidikan Departemen Pendidikan Nasional. 2008. Penulisan Modul. (online), (http:gurupembaharu.com/home/ wp.../26-05-A2-B-PenulisanModul.doc), diakses tanggal 18 Desember 2014

Gall, Gall \&Borg.2003. Educational Research An Introduction( $7^{\text {th }}$ ed)NewYork: Pearson Educational Inc.

Nurgiyantoro, B. 2013. Sastra Anak Pengantar Pemahaman Dunia Anak. Yogyakarta: Gadjah Mada University Press.

Nurhadi. 2009. Membaca. Malang: Asih Asah Asuh

Pusposari, D. 2010. Peningkatan Kemampuan Membaca Cerita Fiksi Realistik Siswa Kelas5 SDN Arjowinangun Malang melalui Booktalk. Tesis tidak diterbitkan. Malang: Universitas Negeri Malang

Setyosari \& Effendi. 1990. Pengajaran Modul (Buku Penunjang Modul). Malang: IKIP Malang

Syafi'ie. 1999. Pengajaran Membaca di Kelas-Kelas Awal Sekolah Dasar. Pidato Pengukuhan Guru Besar dalam Bidang Ilmu Pengajaran Bahasa Indonesia pada Fakultas Pendidikan Bahasa dan Seni disampaikan pada Sidang Terbuka Senat Universitas Negeri Malang, 7 Desember 1999

Tarigan, D. 1997. Kependidikan Keterampilan Berbahasa. Jakarta: Modul Universitas Terbuka

Tarigan, H.G. 2008. Membaca Sebagai Suatu Keterampilan Berbahasa. Bandung: Angkasa 